\title{
Determining Expert Opinions of the Faculty of Education on the Development of Distance Learning Course
}

\author{
https://doi.org/10.3991/ijet.v15i23.18783
}

\author{
Sezer Kanbul $(\bowtie)$ \\ Near East University, Nicosia, Turkey \\ sezer.kanbul@ neu.edu.tr
}

Natalia A. Zaitseva

Plekhanov Russian University of Economics, Moscow, Russia

\author{
Aleksandr I. Ikonnikov \\ Pacific National University, Khabarovsk, Russia \\ Olga A. Kalugina \\ Financial University under the Government of the Russian Federation, \\ Moscow, Russia \\ Tatyana N. Savina \\ National Research Mordovia State University, Saransk, Russia \\ Olga G. Evgrafova \\ Kazan Federal University, Nabereznye Chelny, Russia
}

\begin{abstract}
A modern education system where students and faculty members are not obliged to come to the campus, where live, video, audio and interactive courses are taught in a fully virtual environment with face-to-face university education is called distance education. Based on the technological developments, the importance of distance education has also been revealed. The aim of this study is to determine the opinions of experts on the development of the 'distance education' course brought to the teacher training programmes. The participants of the study were selected from the purposeful sampling types with maximum diversity, criteria and easily accessible sampling methods. The data obtained as a result of interviews with experts from Northern Cyprus and Russian Universities were subjected to content analysis with a qualitative approach. In this study, which was designed as a case study, 20 academicians from 3 different departments working in the education faculty were included. In the study, a semi-structured interview form developed by the researchers was used as the data collection tool. Interviews were recorded with their consent. The data obtained as a result of interviews with experts were subjected to content analysis with a qualitative approach. As a result of the research, the experts reported teacher competencies, course application and system-oriented views for the development of the distance learning course.
\end{abstract}

Keywords - Education, learning, distance learning lesson, programme development, technology, method 


\section{Introduction}

Education is a phenomenon that is on the agenda of all ages and occupational groups. This important issue has been developed with various methods and techniques until today. The use of computers and mobile devices has increased rapidly with the developing and advancing technology [2,29]. This increase in the use of technology has become indispensable for the use of technology in education. Education, which has always been discussed from yesterday to today and has always been of great importance, has gained a different dimension with computers taking their place as indispensable elements of daily life. In addition to traditional education, it can be seen that many institutions and organisations around the world approach distance education with great seriousness. Especially, after the universities were equipped with computer networks, it was inevitable that university lecturers were also interested in distance education, unlike traditional education $[19,25]$. Distance education should be considered together with the educational tool used. It is necessary to evaluate the distance education studies carried out using tools such as letters, television, radio and web-based distance education studies separately. Web-based distance education provides an opportunity for interaction that other types of distance education do $\operatorname{not}[30]$.

Today, the education system is shaped by information and communication technologies. Rapid developments in technology are driving all societies towards an information-intensive life. In recent years, especially in education, the use of computer-based technologies by teachers and students has gained importance $[22,23,24]$. Through the use of search engines fast and efficient communication between individuals through easy to use, users interested in the same topic on the Internet, the information they need quickly produced in this mass of information is more easily accessible than ever before [31]. Developments in the field of information and technology have reached an unprecedented speed. These technological developments accelerated the production of knowledge and caused the acquired knowledge to age rapidly [31].

Computers and other technological tools play an important role in creating rich learning environments, responding to different learning styles of students, transferring what has been learned, supporting higher-level thinking, offering students the opportunity to compare with real-life problems and supporting lifelong learning $[6,15]$. Education programmes, investments in education and education policies are also intensified by knowledge [8,9,10]. Functionally, the transformation and innovation we have encountered in education have made the learning process more efficient by using new teaching tools. As a result, it has the power to renew itself with its flexibility of change, and as a result, a learning-centred approach and a studentcentred education system have come to the fore. Nowadays, student-student interaction is considered as the main process in many online education applications that reflect a constructive view [14].

Instructors, students, technical personnel, consultants and managers are part of the distance education system. Many studies have been conducted both domestically and abroad to determine individuals' attitudes and opinions towards distance education. 
These studies have been guiding to a great extent in determining the direction and form of the distance education method. Distance education systems can be asynchronous or synchronous according to the need. Asynchronous training platforms are training platforms that are prepared in such a way that they can start and finish training whenever they want, regardless of the training provider. Synchronous training platforms are training platforms that are prepared in a way that is dependent on the training provider, that is, it starts and ends simultaneously. It is considered that synchronous and asynchronous applications with the possibilities offered by different technologies are important for effective participation. When the studies in the related literature are examined, many universities are $[1,11,13,18,21,27]$ presented in distance education[20]. It can be seen that the quality of education is gradually increasing, thanks to the different technological possibilities. When the studies were examined, it highlighted the need for training teachers who would teach through distance education. Faculty with a variety of modality knowledge and skills takes into account the characteristics of the modality that requires a properly prepared modality. Accordingly, this work involves understanding whether the required professional development of the faculty is accompanied by a focus on distance education and learning with technology. The literature review in the area revealed that one of the main obstacles pointed out by teachers to teach in distance learning was the development of effective technical skills and the need for training to develop such an activity [16,17]. Since then, little has changed and teacher training still does not occupy the central place in the context of distance education. Compelling evidence demonstrates that training is needed to enable teachers to adapt to new paradigms and tasks that are necessary for today's society [5].

It is a known fact that a good education should be given in schools in order to reach the welfare level of developed countries and to realise education in the most efficient way. However, it is necessary to increase the quality of education in schools in order to provide good education in schools, that is, for students to be successful $[25,26]$.

Due to the pandemic (COVID-19) that affected the world in 2020, the importance of distance education has increased significantly with the transition to distance education. All platforms have been digitalised and trainings have continued. The biggest problem that emerged during this transition process is that the current technological infrastructure is inadequate, and all users (students and teachers) in the technological structure do not have the ability to use very good technical equipment, infrastructure and technology. For this reason, the qualifications of the 'distance education' course have soared, which is given as an elective course in the Computer Science department in the education faculties of universities.

\subsection{Purpose of the research and research questions}

The aim of this study is to determine expert opinions on the development of the 'distance education' course brought to the teacher training programmes. The importance of distance education has increased with technology. Teacher and student competencies are very important in distance education. For this reason, the 'distance 
education' course has been added to the courses given at universities. This study is important in terms of developing this course more effectively.

Based on the purpose, the following research questions were posed:

Question 1: What are the distance education field knowledge competencies of lecturers?

Question 2: What are the advantages and disadvantages of distance education for students and teachers?

Question 3: What are the instructors' views about the distance education course in undergraduate education?

Question 4: What are the recommendations about the distance education course?

\section{Method}

Opinions of academicians were received for the development of the 'distance education' course given in the faculties of educational sciences of universities. The interview technique, one of the qualitative research methods, was applied to achieve the objective of this research. Open-ended questions developed by the researchers were prepared in this research. For the reliability of the questions, the opinions of three experts in their respective fields were obtained and finalised. Since the research was conducted based on collecting opinions with open-ended questions, it can be defined as an unstructured interview [3]. The frequencies were obtained by digitising the qualitative data obtained by the interview technique. During the data collection process, academicians working at universities were called and preliminary information was given about the research, the importance of the research was explained and the meeting days were arranged. In total, 30 academics were arranged for the interviews. However, data were taken from only 20 academics who showed up on the day of the interview. Interviews were recorded and notes were taken. The findings obtained from the interviews were reported, and the final approval was obtained from the academicians. The interview forms were read separately by the researchers and were grouped according to the similarity of the expressions.

\section{Results}

\subsection{Distance education field knowledge competencies of lecturers}

Eight lecturers answered yes, while 12 lecturers answered no to the question of whether you consider yourself competent about distance education. When the teacher candidates working at the university were asked whether or not they received an education related to distance education, it was found that 5 lecturers received training and 15 lecturers did not. The question of where they received education regarding distance education was asked to five instructors who were trained. Three lecturers stated that they received education online from a foreign country and two lecturers wrote their theses via distance education for this reason. 


\subsection{Advantages and disadvantages of distance education for students and teachers}

The answers given by the lecturers regarding the advantages and disadvantages of distance education for students and teachers were shown in Table 1.

Table 1. Advantages and disadvantages of distance education for students and teachers

\begin{tabular}{|l|l|l|}
\hline & \multicolumn{1}{|c|}{ Advantage } & \multicolumn{1}{c|}{ Disadvantage } \\
\hline Teacher & \multicolumn{1}{|c|}{ Tim) } & Getting used to face-to-face education (8) \\
\hline & Participation in independent classes (5) & Low motivation (6) \\
\hline & Rich content sharing (5) & Technological knowledge deficiency (6) \\
\hline & Delivering technology supported education (5) & \\
\hline Student & Time (8) & Getting used to face-to-face education (12) \\
\hline & Participation in independent classes (7) & Passivation (5) \\
\hline & Unlimited opportunity to repeat the lesson (6) & System information insufficiency (3) \\
\hline
\end{tabular}

Positive and negative opinions of lecturers and students about distance education were received. The answers given by lecturers to the question of advantages and disadvantages of distance education for students and teachers were grouped under the titles of teacher and student. The advantages for the teachers were saving time (8); participating in space-independent lessons (5); and adapting technology to his lessons, that is, providing technology-supported education (5). The disadvantages of distance education for teachers were that they were used to face-to-face education (8); it decreased their motivation (6) and lack of technology (6). Instructors' responses to the question of what the advantages of distance education for students were consistent with their answers to the advantages of distance education for teachers. Likewise, they answered the advantages of distance education for students as time (8), location independent (7) and opportunities to repeat the course (6). They responded to the disadvantages of distance education for students that they would have difficulty because they were used to face-to-face education (12) and had sufficient knowledge about the system in which they would passivate (5) students (3). It can be said that the findings obtained are positive opinions.

\subsection{Instructors' views about the distance education course in undergraduate education}

Table 2. Views about the distance education course in undergraduate education

\begin{tabular}{|l|c|}
\hline & f \\
\hline Theoretical content should be increased & 10 \\
\hline Application efficiency should be increased & 10 \\
\hline Should be given in more than one academic year & 8 \\
\hline Certificate programmes & 3 \\
\hline
\end{tabular}


In the findings regarding their opinions about the distance education course given to the lecturers in undergraduate education, they stated that the contents of the distance education courses (10) were insufficient and that the students were poor in this subject. Activities can be increased with programmes that can be used in distance education. Students may be offered the opportunity to practice. During the education, certificate programmes can be arranged every semester and given to both students and teachers. Distance education should be added as an elective course in all undergraduate programmes, and not just as an elective course in education faculties.

\subsection{Recommendations about the distance education course}

When asked if the lecturers wanted to add about distance education, their answers are given in Table 3 .

Table 3. Recommendations about the distance education course

\begin{tabular}{|l|c|}
\hline & f \\
\hline elective course & 17 \\
\hline training on distance education & 8 \\
\hline techniques and activities used in distance education & 5 \\
\hline
\end{tabular}

The lecturers were asked whether there was anything they would like to add lastly. 17 out of 20 lecturers stated that distance education should be taught as an elective course and not only in education faculties but also in all programmes of the university. Eight lecturers stated that both university lecturers and teachers in primary, secondary and high schools should receive training on distance education. There were five lecturers who stated that the techniques and activities used in distance education could be applied not only in distance education but also in face-to-face training.

\section{$4 \quad$ Result and Discussion}

Eight lecturers answered yes, and 12 lecturers answered no to the question of whether you consider yourself competent about distance education. When the teacher candidates working at the university were asked whether or not they received an education related to distance education, it was revealed that 5 lecturers received training and 15 lecturers did not. The result of this finding is quite thought-provoking. Technology has been included in education. Due to the development of technology and occupying a large place in our daily life, the contents of the training programmes have been added to the technology-supported training. It is a pity that the teacher candidates do not overcome the deficiencies of their field knowledge on distance education and other deficiencies. In the study conducted by Duzakin, and Yalcinkaya, [30], Instructors stated that they frequently use the computer to make presentations / demonstrations, practice / practice, measure / evaluate, communication, research on the internet, follow newspapers and benefit from electronic services, video and voice chat, web page, which are important for web-based distance education They stated 
that they do not have many habits such as creating, creating multimedia, participating in discussions and lecture presentation[30].

The answers given to teachers and students from the findings of the researchers about the advantages and disadvantages of distance education for students and teachers are similar to each other. It was concluded that the responses given by the lecturers to the advantages for the teacher provided the most advantage in terms of time-saving. If we look at the findings of the disadvantages of distance education for teachers, it was concluded that teachers thought that the distance education system would be a disadvantage because they were used to face-to-face education. It was also concluded that another disadvantage of distance education was that willing lectures would not take place as in face-to-face education, and that there would be low motivation due to communication not being similar to the face-to-face education. Yet, another disadvantage is that the technological knowledge should be sufficient in order to provide distance education in the right way. However, it was concluded that the effective use of the distance education system due to the lack of technological knowledge in the teachers was not realised. Instructors' responses to the question of what are the advantages of distance education for students are consistent with their answers to the advantages of distance education for teachers. Likewise, it haas been concluded that the greatest advantage of distance education for students iss that it is an education system independent of time and place. Another advantage is that it offers the student the opportunity to repeat as many times as they want. They answered the disadvantages of distance education for students as they would have difficulties because they were used to face-to-face education (12) and they did not have enough information about the system in which they would passivate (5) their students (3). Similarly, it has been concluded that the distance education system has common advantages and disadvantages for teachers and students. As understood from this result, it can be concluded that teachers and students do not have sufficient content knowledge about distance education information. The result of this finding is consistent with other studies. Celen et al. [4] found that distance education lagged behind traditional face-to-face education and attitudes towards distance education were negative. Again, in a similar study, it was found that academics emphasised that 'high-level skills' in distance education cannot be measured; therefore, evaluations should be made face-to-face [28]. In another study, it was concluded that a significant part of the students participating in graduate education programmes came from outside the city, and it was beneficial because the concept of space was eliminated significantly with distance education $[12,17]$.

As a result of the finding regarding the views of the lecturers about the distance education course given in undergraduate education, it was concluded that the students who took the distance education course were theoretically poor. The reason for this can be thought to be that the distance education course is given as an elective course and that all theoretical knowledge cannot be transferred to the students since they only take this course for one semester. It can be concluded that all the features of the programmes used in the distance education course should be taught to the students. The reason for this can be considered as teaching best with the show and do model. It can be concluded that the distance education course should be added and continued, 
not just for a period of education years. During education, certificate programmes can be arranged every semester and given to both students and teachers. Gonzalez [7] showed a similar result in his study, that distance education should be added as an elective course in all undergraduate programmes, not only in education faculties. The urge for internationalisation, flexibility in education and the widespread use of online education on such issues requires instructors to keep up with these developments and encourage change in the field knowledge by using web-based technological tools.

The lecturers were asked whether there was anything they would like to add lastly. Considering the results of this finding, 17 out of the 20 lecturers stated that distance education should be taught as an elective course not only in education faculties but also in all programmes of the university. This result is very gratifying. Distance education is important not only in education but also in every field because eight lecturers stated that both university lecturers and teachers in primary, secondary and high schools should receive training on distance education. Distance education should be used in every field in order to keep up with the technological age. The competencies of the trainers in the field knowledge related to distance education are very important. There are five lecturers who stated that the techniques and activities used in distance education could be applied not only in distance education but also in face-to-face training. According to this result, this result may have been reached because they wanted to differentiate their education with techniques, such as attracting students' attention and interest.

\section{$5 \quad$ References}

[1] Bekele, T. A., \& Menchaca, M. (2008). Research on internet-supported learning: A review. Quarterly Review of Distance Education, 9(4): 373-405.

[2] Bhuyan, M., \& Tamir, A. (2020). Evaluating COs of computer programming course for OBE-based BSc in EEE program. International Journal of Learning and Teaching, 12(2), 86-99. https://doi.org/10.18844/ijlt.v12i2.4576

[3] Buldu, D., \& Armagan, F. (2019). Determination of the opinions of prospective science teachers about the planned trip to the sugar factory. International Journal of Innovative Research in Education, 6(2), 21-39. https://doi.org/10.18844/ijire.v6i2.4474

[4] Celen, F. K., Celik, A., \& Seferoglu, S. S. (2013). Analysis of teachers' approaches to distance education. Procedia-Social and Behavioral Sciences, 83: 388-392. https://doi.org/ 10.1016/j.sbspro.2013.06.076

[5] Cochia, C. B. R., \& de Souza, S. (2013). Educacao a Distancia: elementos para pensar o ensino-aprendizagem contemporaneo. Teoria e Pratica da Educacao, 16(1): 147-149.

[6] Coutinho, C., (2007). Infusing technology in pre-service teacher education programs in portugal: A study with weblogs (pp. 2027-2034). Proceedings of the 18th International Conference of the Society for Information Technology \& Teacher Education, Chesapeake, VA: AACE.

[7] Gonzalez, C. (2009). Conceptions of, and approaches to, teaching online: A study of lecturers teaching postgraduate distance courses. Higher Education, 57(3): 299-314. https ://doi.org/10.1007/s10734-008-9145-1

[8] Isman, A. (2008). Uzaktan egitim. Pegem Akademi. 
[9] Kelkay, A. (2020). Teachers' role in curriculum implementation at primary and secondary schools of Addis Ababa, Ethiopia. Contemporary Educational Researches Journal, 10(2), 28-41. https://doi.org/10.18844/cerj.v10i2.4660

[10] Admiraal, W., Louws, M., Lockhorst, D., Paas, T., Buynsters, M., Cviko, A., \& van der Ven, F. (2017). Teachers in school-based technology innovations: A typology of their beliefs on teaching and technology. Computers \& Education, 114: 57-68. https://doi.org/ 10.1016/j.compedu.2017.06.013

[11] Lammintakanen, J., \& Rissanen, S. (2005). Online learning experiences of university students. In C. Howard, J. Boettcher, L. Justice, K. Schenk, P. L. Rogers, \& G. A. Berg (Eds.), Encyclopedia of distance education (Vol. 3, pp. 1370-1374). Idea Group Reference. https://doi.org/10.4018/978-1-59140-555-9.ch206

[12] Liu, O. L. (2012). Student evaluation of instruction: In the new paradigm of distance education. Research in Higher Education, 53(4): 471-486. https://doi.org/10.1007/s11162$\underline{011-9236-1}$

[13] Fuada, S., Adiono, T. \& Prasetiyo, P. (2005). Accuracy Improvement of RSSI-based Distance Localization using Unscented Kalman Filter (UKF) Algorithm for Wi-Fi Tracking Application. International Journal of Interactive Mobile Technologies (iJIM), 14(16): 225-233. https://doi.org/10.3991/ijim.v14i16.14077

[14] McIsaac, S. M., \& Gunawardena, S. L. (1996). Distance education. In D. Jonassen (Ed.), Handbook of research in educational communication and technology. Simon \& Shuster Macmillan.

[15] Menzi, N., Caliskan, E., \& Cetin, O. (2012). Ogretmen adaylarinin teknoloji yeterliliklerinin cesitli degiskenler acisindan incelenmesi. Anadolu Universitesi Egitim Bilimleri Enstitusu Dergisi, 2(1). https://doi.org/10.35675/befdergi.440393

[16] Talib C. A., (2019). Enhancing Students' Reasoning Skills in Engineering and Technology through Game-Based Learning, iJET, 14 (24): 69 - 80, https://doi.org/10.3991/ijet.v14i24. $\underline{12117}$

[17] Moore, M. G., \& Kearsley, G. (2013). Educacao a distancia: sistemas de aprendizagem online. Cengage Learning.

[18] Novitzki, J. E. (2005). Necessities for effective asynchronous learning. In C. Howard, J. Boettcher, L. Justice, K. Schenk, P. L. Rogers, \& G. A. Berg (Eds.), Encyclopedia of distance education (Vol. 3, pp. 1325-1331). Idea Group Reference. https://doi.org/10.40 18/978-1-59140-555-9.ch198

[19] Pala, F. K. (2006). Uzaktan egitim icin egitim yonetim sistemi ana modulunun hazirlanmasi. Yayimlanmamis Yuksek lisans Tezi, Gazi Universitesi. https://doi.org/10.17 $152 /$ gefad.548437

[20] Lengyel P. S. (2020). Can the Game-Based Learning Come? Virtual Classroom in Higher Education of 21st Century. iJET, 15(2): 112 - 126, 2020. https://doi.org/10.3991/ijet.v15i $\underline{02.11521}$

[21] Pituch, K. A., \& Lee, Y. (2006). The influence of system characteristics on e-learning use. Computers \& Education, 47(2): 222-244. https://doi.org/10.1016/j.compedu.2004.10.007

[22] ]Russell, G., Finger, G., \& Russell, N. (2000). Information technology skills of Australian teachers: Implications for teacher education. Journal of Information Technology for Teacher Education, 9(2), 149-166. https://doi.org/10.1080/14759390000200087

[23] ]Sabirli, Z., \& Coklar, A. (2020). The effect of educational digital games on education, motivation and attitudes of elementary school students against course access. World Journal on Educational Technology: Current Issues, 12(3): 165-178. https://doi.org/10.188 $\underline{44 / \text { wet.v12i3.4993 }}$ 
[24] Salama, R., Uzunboylu, H., \& El Muti, M. (2020). Implementing online questionnaires and surveys by using mobile applications. New Trends and Issues Proceedings on Humanities and Social Sciences, 7(3): 48-70. https://doi.org/10.18844/prosoc.v7i2.5016

[25] Seferoglu, S. S. (2004). Ogretmen yeterlilikleri ve mesleki gelisim. Bilim ve Aklın Aydinliginda Egitim, 58: 40-45.

[26] Seferoglu, S., \& Celen, F. (2020). Improving the use of ICT through online professional development platform based on metacognitive strategies. Global Journal of Information Technology: Emerging Technologies, 10(1): 45-59. https://doi.org/10.18844/gjit.v10i1.47 $\underline{47}$

[27] Soong, M. H. B., Chan, H. C., Chua, B. C., \& Loh, K. F. (2001). Critical success factors for online course resources. Computers \& Education, 36(2): 101-120. https://doi.org/10.10 16/s0360-1315(00)00044-0

[28] Tuncer, M., \& Tanas, R. (2011). Akademisyenlerin Uzaktan Egitim Programlarina Yonelik Goruslerinin Degerlendirilmesi (Firat ve Tunceli Universiteleri Ornegi). Ilkogretim Online, 10(2).

[29] Uzunboylu, H., \& Beheshti, M. (2017). An investigation through content analysis in infographics. The Turkish Online Journal of Design Art and Communication, 7(4): 655666. https://doi.org/10.7456/10704100/011

[30] Düzakin, E., \& Yalçinkaya, S. (2008). Web Tabanli Uzaktan Eğitim Sistemi Ve Çukurova Üniversitesi Öğretim Elemanlarinin Yatkinliklari. Journal of the Cukurova University Institute of Social Sciences, 17(1). https://dergipark.org.tr/tr/pub/cusosbil/issue/4378/6001 $\underline{9}$

[31] Staudt, E. (2001). The future of learning-learning for the future: Shaping the transition. Open praxis: the bulletin of the International Council for Distance Education, 2: 13-15.

\section{Authors}

Sezer Kanbul is with the Department of Computer Education \& Instructional Technology, Near East University. He is also the Director of Distance Education and Information Technologies Center. Him main scientific and professional interests are distance education, digital child rights, digital wellbeing and computational thinking. P.O. Box: 99138, Nicosia, North Cyprus. E-mail: sezer.kanbul@neu.edu.tr

Natalia A. Zaitseva is a Doctor of Economics, Professor of the Department of Hospitality, Tourism and Sports Industry at Plekhanov Russian University of Economics (36 Stremyannyi Pereulok, 115093, Moscow, Russia). Her main scientific and professional interests are connected with professional standards and assessment of personnel qualifications in the tourism and hospitality industry, she actively studies strategic management of tourism development in the regions, the strategy for building human capital at the macro and micro levels, effective management and selfmanagement. She is a member of 3 dissertation councils of some Russian universities for the defense of doctoral and PhD theses. E-mail: zaitseva-itig@mail.ru

Aleksandr I. Ikonnikov is a Doctor of Education, Professor of the Department of the Fine Arts of Teacher's College at Pacific National University (136 Tikhookeanskaya Street, 680035, Khabarovsk, Russia). His research interests for the last decade have been connected with the items of the fine arts in Russian education. He has more than 
50 articles published in international and Russian journals and conferences materials. E-mail: aiikonnikov@mail.ru

Olga A. Kalugina is Associate Professor of the Department of Foreign Languages at Financial University under the Government of the Russian Federation (49 Leningradsky prospect, 125993, Moscow, Russia). Her research interests are related to the methodology of scientific papers, education, language and linguistics. E-mail: kaluginaruc@mail.ru

Tatyana N. Savina is $\mathrm{PhD}$ in Economics, Associate Professor of the Department of Theoretical Economics and Economic Security at the National Research Mordovia State University (68 Bolshevistskaya street, 430005, Saransk, Russia). Her main scientific and professional interests are connected with the problems of social responsibility in business, sustainable development, economic and social security, modern education system and its development. E-mail: savinatn@yandex.ru

Olga G. Evgrafova is PhD in Pedagogy, Associate Professor of the Department of Philology at Kazan (Volga region) Federal University, Nabereznye Chelny Institute (423812, Republic of Tatarstan, Naberezhnye Chelny, 68/19 (1/18), 335). Her research interests for the last decade have been connected with the items of the history of professional education in Russian regions, exactly teachers' retraining in XX century as well as problems of teaching English to students of non-linguistic universities. She has more 20 articles published in international journals and conferences materials. E-mail: olgaevgrafov@gmail.com

Article submitted 2020-09-16. Resubmitted 2020-10-11. Final acceptance 2020-10-11. Final version published as submitted by the authors. 